Copyright @ 2015 SBPjor / Associação Brasileira de Pesquisadores em Jornalismo
INFORMATION

MONOCULTURES: a look at

the production of fragmented narratives

in the press

GABRIELA NÓRA

Universidade Federal do Rio De Janeiro, Rio de Janeiro, Brasil

\begin{abstract}
The concept of "information monoculture", derived from the work of Indian philosopher Vandana Shiva, explores the relationships between the author's analysis in the field of biodiversity and biotechnology, and the problem of hyper-segmentation in journalistic narratives.A careful observation of the logic underlying the monoculture system aids in the understanding and demystification of the segmentation processes in journalism, especially when it comes to those mechanisms that make more of the same to specific groups, in order to eliminate diversity to meetthe much celebrated customization. In this context, it is imperative to discuss the problem of this tendency toward fragmentation and transience these days, paying attention to the modes of appropriation of the real/reality and to the marking of rhythmic flows that intensely affect and define relationships, content, and narrative (and social) experiences of contemporaneity.
\end{abstract}

Keywords: Information monocultures. Press. Narratives. Segmentation. New technologies.

\title{
MONOCULTURAS DA INFORMAÇÃO: um olhar sobre a produção de narrativas fragmentadas no jornalismo impresso
}

RESUMO - O conceito de "monoculturas da informação", desenvolvido a partir do trabalho da filósofa indiana Vandana Shiva, explora a relação entre as análises da autora no campo da biodiversidade e da biotecnologia e a problemática da hipersegmentação das narrativas jornalísticas. A observação atenta das lógicas que subjazem ao sistema de monocultura auxilia no entendimento e na desmistificação dos processos de segmentação no jornalismo, especialmente no que tange aos mecanismos de fabricação de mais do mesmo para grupos específicos, com vistas à eliminação da diversidade para atender à tão celebrada personalização. Neste contexto, torna-se premente discutir a problemática da tendência à fragmentação e à efemeridade nos dias de hoje, atentando para esses modos de apropriação do real e de marcação dos fluxos temporais que afetam e definem de maneira intensa as relações, conteúdos e experiências narrativas (e sociais) da contemporaneidade.

Palavras-chave: Monoculturas da informação. Jornalismo impresso. Narrativa. Segmentação. Novas tecnologias. 


\section{MONOCULTIVOS DE LA INFORMACIÓN: una mirada sobre} la producción de narrativas fragmentadas en el periodismo impreso

RESUMEN - El concepto de "monocultivos de la información", desarrollado a partir del trabajo de la filósofa hindú Vandana Shiva, explora la relación entre los análisis de la autora en el campo de la biodiversidad y de la biotecnología, por una parte, y la problemática de la híper segmentación de las narrativas periodísticas, por otra. Una atenta observación de las lógicas subyacentes al sistema de monocultivo ayuda a entender y desmitificar los procesos de segmentación en el periodismo, especialmente en lo que atañe a los mecanismos de fabricación de contenidos repetidos- más delo mismo- para grupos específicos, con el fin de eliminarla diversidad y así, atender la tan celebrada personalización. En este contexto, resulta apremiante discutir el problema de la tendencia a la fragmentación y a la transitoriedad de la actualidad. Además, parece conveniente reflexionar acerca de los modos de apropiación de lo real y de la marcación de los flujos temporales que afectan y definen, de manera intensa, las relaciones, los contenidos y las experiencias narrativas (y sociales) de la contemporaneidad.

Palabras clave: Monocultivos de la información. Periodismo impreso. Narrativa. Segmentación. Nuevas tecnologías.

\section{CONTEXTUALIZATION}

Historical analysis shows that the segmentation process was widely incorporated by the Brazilian press in the late twentieth century, with the consolidation of sections and beats, and the valuing of journalistic marketing in the 1980s and 90s. Nowadays, in the age of digital media, a period of multiple and discontinuous temporality, marked by a tendency toward hyper segmentation, the need to rethink the model followed by the press is highlighted - both in terms of content and format - so that newspapers have their own space and are not merely reproducing previously disseminated news.

It is possible to observe that journalism celebrates the advent of a new temporality (ephemeral, fleeting) driven by technological advances, adhering more to the practice of segmenting the news. Therefore with the proposition of the "information monoculture" concept based on Indian philosopher, physicist and environmental activist Vandana Shiva's thoughts -the purpose is to not only rethink the current state of journalism, but stemming from the analysis of the fragmented media aesthetics - with emphasis on the press - to investigate the effects of the deepening of the modes of fragmented appropriation / recovery of the world within a practice (segmentation) that would not only be journalistic, but cultural.

Thus, we seek to hypothesize that we live a paradox in the contemporary society: a time when, technically, everything tends to 
move towards convergence, but from the point of view of meaning, and signification, divergence is what seems to be predominant. It is believed that new technologies have accentuated the trend towards the segmentation of cultural products, with serious damages to social integration and the "maintenance of a minimum common cultural horizon"'. In other words, it is assumed that, at the same time that we move towards increased media convergence, the increase of the content of dispersion leads to a higher segmentation/ individualization of the audience.

What can be observed in the age of digital communication is that we are witnessing a shift in the collective function of cultural products to an individual level: music, for example, has always had a collective function, but storage technologies have allowed to displace it to the individual level, omnipresentnowadays. With each customer designing his or her own compilation, there is a crisis in the idea of a whole work (a CD, LP and so forth). The same can be said, in regards to the information industry, where the idea of a whole (in the form of a newspaper, for example) has been losing more and more strength in the face of modern tools of production, distribution, circulation and storage of information.

We can even say that today personalized information invites readers to build their own 'newspaper'. Thus the Internet has subverted the logic of the newspaper itself. Previously, the medium was the focus. The public would buy a particular newspaper, and from it came into contact with the news. Now, the opposite occurs. Individualssearch for keywords on the Internet and arrive directly to their subject of interest. Thus, It is becoming increasingly common for the public to arrive at a certain newspaper or online webpage through the news, and not the other way around.

This inversion of the information process, caused by new technologies and especially the Internet, leads the public to a more direct and targeted information. The individual knows what he wants and where to find it. However, in addition to audience segmentation, and facilitating the work of advertising, this way of consuming information can lead to the formation of closed groups around their own interests. In this context, one has to question the increasingly frequent use of portable electronic devices, such as smartphones and tablets, that use digital language and have as basic support the Internet, with its ability to gather information in various formats (text, sound, image, moving image) and in a single environment 
(multimedia and multiplatform) of technological acceleration and reconfiguration of the notions of time, space, and sociability.

One of the main characteristics of communication within the realm of mobile devices is the intensive use of social media for the exchange of information. In addition to being places for socialization, sharing and interacting, social networks like Twitter and Facebook allow their users to not only access a plethora of information available, as well as the possibility of being consumers, producers and disseminators of information themselves. Therefore, considering that web tools enable any user, journalist or not, to be a diffusing source of events, it is necessary to not only recover the political meaning of mediation, but also to question whether the current newspaper model in fact realizesits role in society.

It is clear that modern technology is bringing significant changes to communications; however, there are many uncertainties about the standards that should be adopted by new media, as well as the changes and / or adaptations that the previous media, including the press, must adopt. Therefore, although this research has focused on the study of segmentation, it fits into this context of change and uncertainty, whether by inserting itself in one of the most pressing issues in the area of communication: the future of journalism.

The Internet is just the latest of many other advances that have contributed to the segmentation of the media. But due to the fact that it meets the demands of those who seek information efficiently, it has accelerated the trend towards smaller audiences. Following this same logic, the mainstream media, having acknowledged the existence of different social groups with specific demands, segments their news, providing the public with blocks of increasingly restricted information.

Additionally, with the consolidation of the Internet as a space for searching and sharing information, where anyone can publish (or post) their own 'news', not only the journalistic profession is put into question, but the very necessity of the existence newspapercompanies. Thus, although the large conglomerates have migrated to the Internet, with all their know-how and credibility, we can speak of new players, new content producers, and sources of information. A new reality that threatens the hegemony of the traditional mass media outlets.

However, and especially because it enjoys a credibility built over the years, we believe in the importance of media culture in establishing a homogenizing pattern. Therefore, the greater the 
diversity and fragmentation amid the plethora of information available at all times, and more and more personalized, the more imperative becomes the standardization in order to reach everyone, to fight the volatility, so that the people have a minimum exchange vocabulary.

\section{INFORMATION MONOCULTURES}

In Monocultures of the Mind: Perspectives on Biodiversity and Biotechnology, Vandana Shiva highlights the unsustainable nature of monocultures, listing a number of technical and production failures caused by this system that eliminates organic diversity in favor of fragmented uniformity. Among the failures measured by the author the change in values stands out, crystallized in overproducing to over consumeinstead of producing to live, as well as the failure evidenced by the economic disaster of this model in which "more food means more hunger 2". Shiva's analysis takes place in the context of biodiversity and biotechnology, dealing therefore to issues mostly related to ecology, which includes questions on agriculture, ecosystems, climate, cropping systems ... and policies in these (and for these) sectors.

However, two failures underlined by the author can be easily applied to the present state of Journalism, when in the consumerism era, there is an overproduction of information (unlimited, immediate, available), but, as we know, not necessarily implying greater knowledge. Instead, the symptoms of disorientation and personal and social destabilization ratify the maximum "more food, means more hunger." In other words, the more information, the more lost individuals and society appear to be.

Hence the importance of paying attention to the logic behind the monoculture system, with all the negative consequences of its implementation, which, it is believed, are closely related to the disastrous results of hyper segmentation process that we have witnessed in journalism. According to Shiva, the problem goes far beyond technology and programs that support the monoculture model. The root of everything is in the dominant ideology, which the author calls "monoculture of the mind", and in the values that guide and justify policies, strategies, and the techniques applied in agricultural and forestry "programs for anti-development ${ }^{3}$ ".

These programs are specially introduced in poor countries 
without any care for the particularity of each region, land and people, disparaging ancient traditions of harvesting, and of a culture of respect to for biodiversity and cycles of life, exclusively in favor of abundance and market efficiency. Through ideological, socio-cultural and economic control, biotechnology and intensive monoculture values are transferred to producers and consumers as if it were useless to them to oppose, since there would be no better system.

Just as bio-imperialismo imposes monocultures, it can be said that the advertising foundation imposes segmentation in journalism, presenting it as the only possible alternative to maintaining efficiency in times of accelerated digital communication. The logic behind it is the same: the market and its need to produce faster and faster, even if it means sacrificing diversity - be it natural (biodiversity) or of opinions. The consequences are also the same: soil impoverishment due to a lack of turnover cultures, and social impoverishment, lack of turnover of ideas. The soil is soon exhausted; becomes unproductive. The groups are soon exhausted; they become unproductive and uninteresting.

Moreover, there is no doubt that "growing the same crop over large areas year after year encourages the increase of pests. The cultivation systems based on diversity have thus an innate protection"'(SHIVA, 2003, p. 97). In the case of journalism, we must constantly seek that protection, since the 'plagues' of prejudice, ignorance, of misunderstandings, of absolute certainties, and of universal thinking grow as the news, and also the public, are fragmented into blocks and closed groups about themselves, which day after day threaten to break the social cohesion.

Shiva argues for the importance and value of a production of diversity for sustainable development, noting that a possible solution to the issues faced would not be in the technical aspect, but situated at the level of will and political power. To discuss the causes of the disappearance of diversity and the challenges of its preservation, the author makes $A$ habit of thinking in terms of monocultures - the "monoculture of the mind" - as the main threat to life:

The monocultures of the mind make diversity disappear from perception and therefore the world. The disappearance of diversity corresponding to the disappearance of alternative - and leads to TINA (there is no alternative) syndrome. How often, in contemporary times, the total uprooting of nature, technology, communities, and entire civilization is not justified on the grounds that "there is no alternatives"? Alternatives exist, but are excluded. Their inclusion requires a context of diversity. Shifting to diversity as a mode of thought, a context of action, allows multiple options to emerge ${ }^{5}$ (SHIVA, 2003, p. 15) 
Thus the author argues she defends diversity in nature and in culture. But why not also defend it in journalism? The field lacks an integrated organic diversity, as opposed to a fragmented uniformity or to uniform fragments - of information and people. "Human diversity is something to be felt more than to be understood," states Muniz Sodré, drawing attention to the fact that, "in fact, men are not equal, or unequal. Menare unique beings coexisting spatially in their diversity. (SODRÉ, 2012, p. 181).

More of the same for specific groups, given the much-celebrated segmentation. While it is said that the alternatives are endless, in fact what we have are blocks of restricted information, customized and designed to meet unique demands. The logic of segmentation does not allow diversity to exist (of ideas, opinions, themes, and contexts) in the same news story. What we have is an abundance of available information. Each one reads or access what interests him/her the most, without necessarily seeking / finding any effective diversity. In short, diverse and diversified are the possibilities of choice. But diversity as multiplicity of interactions is something else.

Protecting native seeds is more than simply conserving raw material for the biotechnology industry. The seeds being pushed to extinction carry within them seeds of others ways of thinking about nature, and other ways of fulfilling our needs [...] Uniformity and diversity are not just ways of using the soil, but ways of thinking and living 6 . (SHIVA, 2003, p. 17)

What would be the "native seeds" of journalism? Would there be other ways to think and practice it nowadays? Shiva discusses and rejects some myths that monocultures would be essential to solve the problem of shortage and to increase production, and that there would be no other option but to destroy diversity "the high productivity of uniform and homogeneous systems is a contextual and theoretically constructed category, based on taking only one-dimensional yield and output into account" (SHIVA, 2003, p. 164). In fact, to act in the strict plane of uniform systems is apparently more productive and less laborious, especially in journalism, where contextualizing stories, searching for relationships and connections, articulating facts and ideas, requires more research and more work. However, would it not also be a myth that,in order to meet the increasingly specific demands in the context of technological acceleration and the scarcity of time, you mustcustomize? Undoubtedly yes, because in order to inform well it is not necessary to inform in a specific way.

"Monocultures first occupy the minds and then are transferred 
to the soil7", states Shiva, adding thatmental monocultures not only destroy diversity, but also "legitimize destruction as progress, growth and improvement." Therefore, according to the monoculture mindset, productivity seems to increase by eliminating of diversity and its substituting it with uniformity ${ }^{8}$. (SHIVA, 2003, p. 17)

In fact this is the mentality of the newsrooms, when, in the name of productivity, journalists are divided into beats and thus form more or less cohesive groups around the same issues. People used to launch a specific and often addicted look at the facts they cover, that are accustomed to a given routine, with delineated sources and with their own language.

It is therefore in the name of productivity that people are denied the possibility of a more plural and diverse consumption. Specific groups produce for specific consumers, according to a qualitatively and quantitatively depleted system. However, as Shiva points out, it is not due to increasing production, but precisely due to increasing control that this mono-cultural mentality spreads: "the expansion of monocultures have more to do with politics and power than with enriching and enhancing systems of biological production(...) uniformity goes hand in hand with centralization while diversity demands decentered control" (SHIVA, 2003, p. 18-19).

According to Shiva, as a metaphor, the monoculture of the mindis best illustrated in the knowledge and practice of separation, operated by 'scientific' systems between forestry and agriculture, from which to the first, only the supply of wood is allowed, not having in itself any other connection with food production. In deleting the cognitive space that related forestry to food, they create fragmented categories, so that, according to the author, eyes close to entire spaces, to integrity, and to diversity. The possibility of the forest to contribute, through fertility links with water, fodder and fertilizer to agriculture. So, once broken, the links between forest and agriculture, the forest is no longer perceived as a food source.It loses its integral value, with all its diversity, since it is then restricted to the market value of industrial wood. into separate, non-overlapping domains, on the basis of separate commodity, Market research to which they supply raw materials and resources. [...] The plant world is not artificially separated between a forest supplying commercial wood and agricultural land supplying food commodities. The forest and the field are in ecological continuum. (SHIVA, 2003, p. 25, our emphasis) 
Similarly, in the social sciences and especially in the case of an activity as journalism, one cannot ignore the continuum of life. In other words, as explained by Louis Quéré, "in actual experience, there is no isolated event", since it is always part of the world - the "whole complete environment" - that one experiences (QUÉRÉ, 2005, p. 70). Therefore, we must keep in mind that "we live and act in connection with the existing environment, not in connection with isolated objects, even when one single thing may have a crucial meaning to decide on how to respond to the total environment" (DEWEY apud QUÉRÉ, 2005, p. 71).

However, as demonstrated by Shiva, when diversity loses its value - through selective annihilation of parts that are not "useful" from the marketing point of view - monoculture emerges as the only "productive" and "high yielding" system. This is what happens in journalism when, for example, by identifying preferences and data collection of users, fragmented narratives are built, producing and supplying informative content on demand.Not only targeted advertising, but the news itself planned according to the user profile / player, in order to optimize production and increase profits.

\section{FRAGMENTED NARRATIVES}

To the fragmentation that presides in the newspapers, with their contiguous stories that in common only have the simultaneity of time, were added to the sphere of mediated culture, many other forms of juxtaposition of images and texts, with which we began to coexist daily (FOLLAIN, 2009, p. 133).

The current societal dynamics, moved by the desire for unbridled consumption and the acceleration of the exchange of goods and information processes, necessitates rapid and complete ownership of time. In this sense, as Olgária Matos notes, "both the informative media and the entertainment aimed at a consumer audience, seek a consuming public, also consuming their values: ideology of easiness, speed in retrieving the message, regulation of time and of reflection" (MATOS, 2006, p. 15).

A context that is characterized by a "fragmented culture", which, according to Vera Lucia Follain, reproduces "the superficial way of acquiring knowledge that the acceleration of time and the omnipresence of the mass media in daily life end up favoring" (FOLLAIN, 2005, p. 91). Thus, the author speaks of a "de-fablelization 
of the narrative"and of a "narrative abyss" - quite common in this scenario of the proliferation of reports without any engagement with fixed references, and in which

[...] More and more space opens up among us for the short narrative, which is characterized by the condensation time, the dry and abrupt cut of the scenes, [...] a symptom of the distrust in the conducting wires that imprint meaning to facts, in the temporality that guide them through the principle of causality, of the interpretative discourses that order them teleologically (FOLLAIN, 2005, p. 84).

In other words, nothing can escape and everything should be seized as soon as possible. Hence the need to fragment the real, to subdivide it as many times as necessary to facilitate the continuous and rapid flow of data and messages, so that the multiplication of fragmentation enables individuals to build purely subjective experiences, nontransferable, Incommunicable.

Thus, we approach the moment denounced by Walter Benjamin, the weakening of the story, the progressive inability of men to share experiences - the main symptom of the decline of the art of narrating, for which, already in 1936, the author drew attention to, highlighting the role of the press: "the principles of journalistic information (news, brevity, clarity and, above all, the absence of any correlation between the news, taken one by one) contribute to this result" (BENJAMIN, 1989, p. 107, our emphasis). Namely: the difficulty of narrating / exchanging experience; understood in its Benjaminian sense, not as lived but as nuisance, disorder, so it can be said that "this loss of communicable experience entails a divorce between man's inner interests and those of his collective life" (Muricy, 1986, p. 74). (MURICY, 1986, p. 74).

\begin{abstract}
Information only has value when it is new. It lives only then, it has to completely surrender itself to it, and without losing time, it has to explain itself in it. The narrative is very different. It does not give in. It retains its strength and after a long time it is still able to be developed [...] to inspire awe and reflection ${ }^{10}$ (BENJAMIN, 1987, p. 204)
\end{abstract}

Therefore, Benjamin speaks of the narrative as a handcrafted way of communicating, different from information, which according to him, would be interested in conveying the "pure end" of the narrated object. Quoting Paul Valéry, the author denounces that, "modern man no longer works at what cannot be abbreviated" the German thinker adds so as to leave no doubt as to his argument: “ 
has succeeded in abbreviating even storytelling"(BENJAMIN, 1987, p. 206). And concludes:

\begin{abstract}
The art of storytelling is coming to an end. Less and less frequently do we encounter people with the ability to tell a tale properly. More and more often there is embarrassment all around when the wish to hear a story is expressed. It is as if something that seemed inalienable to us, the securest among our possessions, were taken from us: the ability to exchange experiences (BENJAMIN, 1987, p. 197)
\end{abstract}

Add to this loss, in the case of print journalism, the inability to cross data and information. The news is presented in a fragmentary way, as if the news was self-explanatory, self-affirmative. However, all information is necessarily relational. But the objective pretense to grasp the information entails forgetting the relational aspect, leaving only what is given. This is what states Muniz Sodré, highlighting the fact that with the Internet, the relationship more and more set aside in favor of short and fast stories (SODRÉ, 2009).

Thus, in order to give another meaning to the problems raised by Benjamin, it is necessary, as suggested by Fernando Resende, to understand the act of narrating not as one stemming just from orality, since it is, par excellence, the product of the basic human need to tell and retell stories. In other words, according to Norval Baitello Jr.,

To narrate meant and means to man assign connections and meanings, turning the facts raised by your perception in more or less complex symbols (...), in sequences, chains, associations of a few or many signifying links (apud RESENDE, 2009, p. 34).

Therefore, the act of narrating is, according Resende, prevenient from the need to establish ways of comprehending and understanding of the world. And thus, especially today, it may be born in different places where life happens. In other words, contrary to what Benjamin claimed, for Resende, the romance, the news reports and the news are also types of narratives, as in some way, they "recount and create meaning - and therefore narrate - the experiences of men in the world" (RESENDE, 2009, p. 34).

Thinking about the relationship between time and narrative, French theorist Paul Ricoeur presents the idea that the text, in other words, the preconfigured world (mimesis II) refers to a prefigured world (mimesis I) and gives rise to a reconfigured world (mimesis III). And it is in this configured world, more specifically in the weaving of the plot - a mimesis hinge device - that, he states, narrative and 
time meet: "time becomes human time insofar as it is articulated in a narrative way, and [...] the narrative reaches its full meaning when it becomes a condition of temporal existence" (RICOEUR, 1994, p. 85, author's emphasis) ${ }^{11}$.

However, the narrative is not only present in mimesis II, but in an entire the plot in before and after, because, even if one can assume 'author in I', 'text in II' and 'reader in III', the three mimesis should be thought of together - "the challenge is thus the concrete process by which the textual configuration mediates between the preconfiguration of the practical field and its reconfiguration the reception of the work" (RICOEUR, 1994, p. 86) -, since there is no dilution of the author, the immanence of the text, or the autonomy of the reader. In other words, narrative should be thought of as "Happening in time" in other words, what is happening in the relationship between the three mimetic modes that constitute the mediation between time and narrative. After all, to look at communication is to look at the happening world to an object that is stagnant ${ }^{12}$.

And, although we recognize that events, not necessarily narrated, but that are produced from a structure of plot "are characterized by their power to clarify the context of the whole, of revealing the existing states of affairs and highlighting the ongoing processes" (QUÉRÉ, 2005, p. 71), one should not overlook the fact that, precisely because it is in "Happening", the narrative is not an organizing speech. It presupposes both order and disorder.

However, we can observe a certain nostalgia for order, or, what is worse, fear of chaos, leading, as pointed out by Ricoeur, some thinkers and critics to oppose in a non-dialectical way the consonance character of the narrative to the dissonance experience of temporality. However, according to the French theorist, "the constitution of the plot is never the simple triumph of "order"' and also to recognize the "schematizing power, intrinsic to productive imagination," he "does not abolish the fundamental dialectic of "discordant concordance", in other words, the temporal experience is not reduced to simple discordance and the narrative is either purely consonance (RICOEUR, 1994, p. 113)

This is also stated by Follain (2009), noting that the notion that the narrative serves as anchor amid the world's fragmentation is also an illusion, since the narrative, which is also fragmented, does not order the world and therefore it should not be seen as the only place of reference in a disordered world. Meanwhile, we must always remember and recognize that the fragmented fabric, whatever it may 
be, does not imply, however, that the reader can not make their own "seams",giving different meanings to the world he sees, reads, hears and in which he interacts in various ways.

After all, as explained by Ricoeur, the notion of identical meaning presupposes univocal conditions that would only would take place in the logical-mathematical discourse. And considering that "an unequivocal expression is insensitive to all contextual variation because its meaning is established by definition or [and] position, a polysemic expression, in contrast, not only is context sensitive, but is determined contextually" it is said, along lines with the French thinker that, in ordinary language, reigns therefore polysemy - although it is recognized that the aim of discourse is to reduce it "and to say one thing and one thing only. ${ }^{13 "}$ (RICOEUR, 2005, p. 37)

This is because, according Ricoeur, what is eminently communicable in a text, is not the author's intention, what he meant, but of what the text talks about, its subject, that is, the non ostensive references that are nothing but "propositions of a world offered by the text, (...) the possible ways of being in the world that the text opens up and reveals" (RICOEUR, 2005, p. 42). Thus, "ultimately what is communicated, is beyond the meaning of a work, a world it designs and constitutes its horizon", so in that sense, the listener or reader receive it according to their reception capacities, they too, limited and opened to a certain world view ${ }^{14}$ (RICOEUR, 1994, p. 119).

Therefore, agreeing with Vera França that the subject of communication is mainly a subject in experience, the idea is ratified that, although summoned by the publication of a text, given as framing structure, "subjects respond within this framework bringing other references: 'brokered', inserted within the knots of a net, they update in that experience, previous ones" (FRANÇA, 2006, p. 84).

Therefore, as well warned by Resende, to understand the narrative as a place of knowledge production implies emphasizing the concept of "journalism as an activitystemming from a dynamic space in which power strategies are articulated and as part of a process in which representations and mediations are inseparable". A space in which "consonance and dissonance [are] established by active subjects that together, and in the friction of their affinities and differences, build [with the media] their shared world" (FRANÇA apud RESENDE, 2009, p. 36). 
Therefore, we must understand the narrative in the world, as opposed to an "immanent reading of the text" in other words, also considering the socio-historical context, apart from the message, the medium, author and recipient. Because the narrative is not something loose in the world, an absolute subject, but is under the influence of various forces, cultural and historical dynamics. Therefore, even if they lead to different readings, narratives are not loose, do not take place outside the world since somehow, they are part of a context, "the act of narration, through the media, may reveal legitimizations, values, representations and lacks, preponderant facts for the process of understanding and reading of the world"(RESENDE, 2009, p. 33). Therefore, cultural, social, political and economic issues, and historical differences, as well as peculiarities of the enunciation gesture should be considered when thinking about the narrative.

Moreover, it is imperative to keep in mind that the narrative (especially mediated ones), as a place of production of meaning, invents and constructs the world, so if there is no narrative outside the world, whatever it is, it will always be taken by power relations. For this reason, "we must analyze and deconstruct the language and behavior to decipher the ideological thought patterns inscribed in them ${ }^{15}$ " (HALL, 2003, p. 164), bearing in mind that there is no social practice outside cultural or ideological categories, since, as heralded by Stuart Hall,

[...]lt is within cultural representation systems and through them that we "experience the world": the experience is the product of our intelligibility codes, our interpretation schemes. Consequently, there is no experience outside the categories of representation and ideology ${ }^{16}$ (HALL, 2003, p. 171).

Thus, a look at the configuration of the narrative that accounts for unveiling these strategies is defended. An understanding of a look that can see contradictions, so not to keep reiterating the discursive order. A look that gazes at the narrative, but also beyond it, i.e., to the prefigured world, to the historical, social, political, cultural context; not only to what the narrative says, or who says it, but how it is said. And this how encompasses Ricoeur's mimetic circle, in other words, this how is not isolated. It is therefore a look at the configured in order to talk about the prefigured, namely to bring to light issues that are beyond the text, covering the three moments of mimesis.

Therefore, we aim to look at the press to understand 
journalism as an institution that produces meaning, so that the newspaper becomes a pretext to discuss the issue of the tendency to fragmentation and transience nowadays.Therefore, adopting a critical attitude towards the realistic narrative - the one that claims to account, explain and cover everything - and, considering that the look at the narrative does not welcome the idea of "order" as an absolute value, it seeks to find truths, reasons for being, but rather ask, discuss, question, and point out other ways than those that are practiced in segmentation.

Therefore, to look at the narrative in order to think the prefigured world, so that the questions are less in relation to its content than about the way the narrative appears that is, how it is constructed, and what kind of world it reveals, according to the segmentation logic of newspapers beats, sessions and related subject maters. To look at newspapers in this way mean to destroy the current segmentation model. Destroying, as proposed by Benjamin, not for the sheer joy of destruction or because you have a better proposition to replace it with, but for the opportunity to open up new and unexpected ways, "the destructive character is not fixed in an ideal image. It has few needs, and the least important of these would be: knowing what will replace what has been destroyed" (BENJAMIN, 1986). Or simply destroying to 'remove the compactness', 'take away the weight of things', to in a Foucauldian fashion, bring up the "games of truth" built throughout history.

\section{FINAL CONSIDERATIONS}

The monocultural way of thinking is not present only on the Internet or on social networks. Although the digital space has intensified the segmentation process, they have always existed as a paradigm for the organization of knowledge and therefore the information. However, what is noteworthy is the accelerated process of hyper segmentation that has followed at a time when, paradoxically, there is so much talk about convergence. In fact, information monocultures act in a particular way in the current environment of information disorientation, in which segmented information - disconnected and decontextualized - do not find a conducive place to rest, a space dedicated to the investigation, 
research and mainly, for the careful consideration of facts. A space that entails, yes, doubt and uncertainty, but that seeks to work them out from a pluralistic perspective.

Thus, a space, where journalism can not only act to establish a minimum of order in the flow of digital information networks, but one which may go beyond absolute truths. A space from which to speak again on the shared experiences of the media, but not due to the fact of having a media center broadcasting for a mass audience, but by having a communication that really interests a large portion of the population, because it is truly committed to social issues without lacking contradictions, valuing diversity, complexity and multiplicity, inherit of human nature and of life in society.

Whether this space is the press, only time will tell. But in reality, it hardly matters. After all, who said the news should come on paper, in texts published once a day, from a newsroom? Can newspapers be saved? Will the press still exist? These are the wrong questions to ask. The right question is: How can we improve journalism? How can we change it (for the better) in the same way that the habits, needs and the public skills in dealing with information have changed?

\section{Notes}

1 Expression preferred by Jesús Martín-Barbero during the workshop Cartografias da sensibilidade e da tecnicidade. Rio de Janeiro: PPGCOM ECO/UFRJ, 2008/2.

$2 \mathrm{Id}$

3 Id.

4 Id.

5 Id.

$6 \mathrm{Id}$.

7 Id.

8 Id. 
9 Id.

10 Id.

11 Id.

12 Id.

13 Id.

14 Id.

15 Id.

16 Id.

\section{References}

BENJAMIN, Walter. Charles Baudelaire: um lírico no auge do capitalismo. Obras Escolhidas vol. III. São Paulo: Brasiliense, 1989.

Documentos de cultura, documentos de barbárie: escritos escolhidos.São Paulo: Cultrix/Edusp, 1986.

FOLLAIN, Vera. Encenação da realidade: fim ou apogeu da ficção?Revista Matrizes, São Paulo, ano 3, n.1, p.131-143, ago/dez, 2009.

Dez anos desinventando a nação: capitais voláteis e narrativas sem lastro. In: MARGATO \& COMES (Orgs.). Literatura/Política/Cultura: (1994-2004). Belo Horizonte: Editora UFMG, 2005, p.83-94.

FRANÇA, Vera. Sujeito da comunicação, sujeitos em comunicação. In: FRANÇA \& GUIMARÃES (Orgs.). Na mídia, na rua: narrativas do cotidiano. Belo Horizonte: Autêntica, 2006, p.61-88.

HALL, Stuart.Da diáspora: identidades e mediações culturais. Belo Horizonte: Editora UFMG, 2003.

MATOS, Olgária. Discretas esperanças: reflexões filosóficas sobre o mundo contemporâneo. São Paulo: Nova Alexandria, 2006.

MURICY, Kátia. Tradição e barbárie em Walter Benjamin. Revista Gávea, v.3, Rio de Janeiro, 1986, p.69-77. 
QUÉRÉ, Louis. Entre o facto e sentido: a dualidade do acontecimento. Trajectos: revista de comunicação, cultura e educação, n.6, p. 59-75, 2005.

RESENDE, Fernando.O jornalismo e suas narrativas: as brechas do discurso e as possibilidades do encontro. Revista Galáxia, São Paulo, n. 18, p.31-43, dez. 2009.

RICOEUR, Paul. Discours et communication. Cahier de L'Herne Ricoeur, n.81. Paris: Éditions de L'Herne, 2005.

Tempo e narrativa: a tríplice mimese. Tempo e narrativa. v.1. Campinas: Papirus, 1994, p.85-131.

SHIVA, Vandana. Monoculturas da mente: perspectivas da biodiversidade e da biotecnologia.São Paulo: Gaia, 2003.

SODRÉ, Muniz. Reinventando a educação: diversidade, descolonização e redes. Petrópolis, RJ: Vozes, 2012.

A narração do fato: notas para uma teoria do acontecimento. Petrópolis, RJ: Vozes, 2009.

GABRIELA NÓRA is a journalist and a professor at Universidade Federal do Rio de Janeiro (UFRJ). She has a PhD in Communication and Culture from Universidade federal do Rio de Janeiro and a member of Laboratório de Estudos em Comunicação Comunitária (LECC-ECO/UFRJ). gabriela. nora@yahoo.com.br 